\title{
EDUKASI PERAWATAN PERIANAL TERHADAP RISIKO KERUSAKAN INTEGRITAS KULIT PADA ANAK DIARE
}

\section{EDUCATION OF PERIANAL CARE TO THE RISK OF DAMAGE SKIN INTEGRITY IN CHILDREN WITH DIARRHEA}

\author{
Desi Kurniawati ${ }^{1}$, Dzul Istiqomah Hasyim ${ }^{2}$ \\ ${ }^{12}$ Universitas Muhammadiyah Pringsewu \\ Email: desi_kurniawati04@yahoo.com
}

\begin{abstract}
Abstrack: Education of perianal care to the risk of damage skin integrity in children with diarrhea. Diarrhea is a disease that is often suffered by toddlers. Stool that is liquid in children can cause skin injury due to frequent repeated contact, which can damage the perianal tissue. This study aims to identify the impact of perianal care education in children under five with diarrhea on the risk of damage to skin integrity in Lampung Regional Hospital. The research design used in this study is a quasi experiment with pre-post test without control group design with 48 respondents selected using consecutive sampling technique. The results showed that there was a significant difference between knowledge and risk of damage to skin integrity after treatment in the control group and the intervention group $(\mathrm{p}<0.05)$. Based on these results, perianal care education can be recommended as an alternative to nursing care in overcoming the risk of damage to skin integrity.

Key words: diarrhea, perianal care education, risk of damage to skin integrity,
\end{abstract}

\begin{abstract}
Abstrak: Edukasi Perawatan Perianal Terhadap Risiko Kerusakan Integritas Kulit Pada Anak Diare. Diare merupakan salah satu penyakit yang sering diderita oleh balita. Feses yang berbentuk cair pada anak dapat menyebabkan cedera kulit akibat seringnya kontak berulang, sehingga dapat merusak jaringan perianal. Penelitian ini bertujuan untuk mengidentifikasi dampak edukasi perawatan perianal pada anak balita dengan diare terhadap risiko kerusakan integritas kulit di RSUD Lampung. Desain penelian yang digunakan dalam penelitian ini yaitu quasi experiment dengan pre-post test without control grup design dengan 48 responden dipilih menggunakan teknik consecutive sampling. Hasil penelitian menujukkan adanya perbedaan selisih yang bermakna antara pengetahuan dan risiko kerusakan integritas kulit setelah perlakuan pada kelompok kontrol dan kelompok intervensi $(\mathrm{p}<0,05)$. Berdasarkan hasil ini maka edukasi perawatan perianal dapat direkomendasikan menjadi salah satu alternatif asuhan keperawatan dalam mengatasi masalah risiko kerusakan integritas kulit.

Kata kunci: diare ,edukasi perawatan perianal, risiko kerusakan integritas kulit,
\end{abstract}

\section{PENDAHULUAN}

Tujuan pembangunan Sustainable Development Goals (SDGs) salah satunya yaitu meningkatkan gizi dan menjamin kehidupan yang sehat dan mendorong kesejahteraan bagi semua orang disegala umur. Upaya yang dilakukan dengan mengembangkan pelayanan kesehatan dinegara berkembang, dengan cara menentukan pelayanan kesehatan yang adekuat, promosi kesehatan untuk merubah gaya hidup dan upaya menurunkan angka kesakitan (WHO, 2012). Diare pada balita menjadi salah satu perhatian pemerintah. Hal ini dikarenakan balita merupakan penderita diare paling banyak. Setiap tahunnya kurang lebih 500 juta anak menderita diare di seluruh dunia setiap tahunnya dan $20 \%$ kematian pada anak yang hidup dinegara berkembang berhubungan dengan diare serta dehidrasi (Wong, Hockenberry-Eaton, Wilson, Winkelstein, \& Schwartz, 2009).

Definisikan diare menurut (World Health Organization/ WHO, 2009) adalah pengeluaran feses dalam bentuk berair tiga kali per hari atau lebih sering dari biasanya. Sementara itu menurut 
Marcdante, Kliegman, Jenson, dan Behrman (2014) diare merupakan jumlah pengeluaran feses yang abnormal dan konsistensi tinja yang lebih encer/cair dalam sehari (>10 mL feses/kg berat badan/hari). Diare merupakan gejala umum dari infeksi gastrointestinal yang disebabkan oleh berbagai macam patogen termasuk bakteri, virus dan protozoa. Penyakit diare pada anak ini menimbulkan berbagai masalah keperawatan diantaranya adalah kerusakan integritas jaringan kulit yang berhubungan dengan iritasi karena defekasi yang sering dan feses yang cair, (Wong, Hockenberry-Eaton, Wilson, Winkelstein, \& Schwartz, 2008).

Feses yang berbentuk cair pada anak dengan diare dapat menyebabkan cedera kulit akibat seringnya kontak berulang, sehingga dapat merusak jaringan perianal jika tidak dilindungi (Cooper, 2011; Nazarko, 2007 dalam Bianchi, 2012). Diare jika dibiarkan dapat mengakibatkan terjadinya kerusakan integritas kulit. Hal ini sering ditemukan pada bayi. Kejadiannya bervariasi antara 4-35\% dalam 2 tahun pertama kehidupan, lebih banyak terjadi pada bayi dengan diare. Iritasi dapat terjadi akibat kontak lama antara urin dengan feses yang disebabkan oleh pemakaian popok. Sehingga dalam waktu yang lama dapat menimbulkan gesekan dari popok (Peristein, 2013).

Daerah yang rentan terjadinya iritasi yaitu vulva, skrotum, anus, bokong, koksigius dan bagian dalam atau atas. Kulit perianal yang mengalami kerusakan jaringan kulit akan meningkatkan risiko infeksi. Risiko yang muncul berupa infeksi sekunder oleh bakteri dan jamur seperti candida albicans yang mempengaruhi lama rawat (Bianchi, 2012). Pencegahan dilakukan dengan perawatan kulit untuk mencegah risiko kerusakan integritas kulit.

Perawatan kulit untuk menurunkan kejadian kerusakan integritas kulit dapat dilakukan dengan membersihkan daerah kulit dengan lembut, dan pemberian pelembab kulit untuk melindungi kulit dari kerusakan jaringan lebih lanjut (Beeckman, 2009 dalam Bardlsey, 2013). Berdasarkan Profil Rumah Sakit Umum Daerah Pringsewu tahun 2015 menyebutkan bahwa diare menduduki posisi 4 besar dari 10 besar penyakit rawat inap yaitu 280 kasus. Sedangkan di ruang rawat inap anak menduduki peringkat pertama sebesar 173 anak menderita diare, kemudian diikuti penyakit DHF menduduki posisi kedua. Hasil wawancara dengan kepala ruangan anak menyebutkan dari 7 anak yang dirawat dengan diare terdapat 3 anak yang mengalami iritasi daerah perianal. Hal ini terjadi pada anak dengan diare yang lebih sering dan kurang pengetahuan ibu dalam melakukan perawatan perianal pada anak dengan diare. Berdasarkan hasil wawancara tersebut peneliti tertarik melakukan penelitian yang berjudul edukasi perawatan perianal terhadap risiko kerusakan integritas kulit pada anak diare di RSUD Pringsewu.

\section{METODE}

Penelitian ini merupakan penelitian jenis kuantitatif dengan pendekatan quasi eksperiment, menggunakan rancangan pre dan post test with control group. Waktu penelitian dilaksanakan pada bulan Januari-Juni 2017 di ruang anak RSUD Pringsewu. Populasi dalam penelitian ini adalah semua balita dengan diare yang dirawat di RSUD Pringsewu Lampung. Sampel penelitian ini adalah balita dengan diare yang dirawat diruang anak RSUD Pringsewu Lampung berjumlah 48 anak. Tehnik pemilihan sampel dalam penelitian ini adalah consecutive sampling dan analisis data yang digunakan pairet $\mathrm{t}$ tes. 
Vol 10 No 1 Januari 2021 | Page 64-68

\section{HASIL}

Hasil penelitian sebagai berikut:

Tabel 1. Perbedaan Pengetahuan dan Risiko Kerusakan Integritas Kulit Sebelum Perlakuan pada Kelompok Kontrol dan Kelompok Intervensi.

\begin{tabular}{lccc}
\hline Variable & Mean & SD & P value \\
\hline Pengetahuan & & & \\
Kontrol & 51,75 & 10,46 & 0,656 \\
Intervensi & 50,25 & 12,63 & \\
\hline Risiko Kerusakan Intrgritas Kulit & & & \\
Kontrol & 7,21 & 1,02 & 0,307 \\
Intervensi & 7,46 & 0,77 & \\
\hline
\end{tabular}

Berdasarkan tabel 1 didapatkan data pengetahuan dan risiko kerusakan integritas kulit sebelum perlakuan. Nilai rata-rata pengetahuan sebelum perlakuan pada kelompok kontrol sebesar 51,75(SD 10,46) hampir sama dengan kelompok intervensi sebesar 50,25 (SD 12,63). Hasil uji statistik menunjukkan bahwa tidak ada perbedaan yang signifikan rata-rata pengetahuan ibu sebelum perlakuan pada kelompok kontrol dan kelompok intervensi (nilai $\mathrm{p}=0,656$ ). Hal ini menunjukkan bahwa data pengetahuan pada kelompok kontrol dan intervensi sebelum perlakuan adalah homogen, sehingga layak untuk dilanjutkan penelitian.

Tabel 2. Perbedaan Pengetahuan dan Risiko Kerusakan Integritas Kulit Sesudah Perlakuan pada Kelompok Kontrol dan Kelompok Intervensi

\begin{tabular}{lcccc}
\hline Variable & Mean & SD & Median & P value \\
\hline Pengetahuan & & & & \\
Kontrol & 55,00 & 11,28 & 59,0 & 0,016 \\
Intervensi & 62,79 & 12,35 & 63,0 & \\
\hline Risiko Kerusakan Intrgritas Kulit & & & & \\
Kontrol & 6,54 & 0,77 & 6,0 & 0,829 \\
Intervensi & 6,46 & 0,65 & 6,0 & \\
\hline
\end{tabular}

Berdasarkan tabel 2 didapatkan data pengetahuan dan risiko kerusakan integritas kulit setelah perlakuan. Nilai rata-rata pengetahuan setelah perlakuan pada kelompok kontrol sebesar 55,0 (SD11,28) lebih rendah dibanding dengan kelompok intervensi sebesar 62,79 (SD 12,53). Hasil uji statistik menunjukkan bahwa ada perbedaan yang signifikan rata-rata pengetahuan ibu sebelum perlakuan pada kelompok kontrol dan kelompok intervensi $(\rho=0,016)$. Hal ini menunjukkan bahwa ada pengaruh signifikan pemberian edukasi perawatan perineal pada ibu yang balitanya mengalami diare.

\section{PEMBAHASAN}

Penelitian ini menghasilkan variabel pengetahuan menunjukkan adanya perbedaan yang signifikan sebelum dan sesudah perlakuan pada kelompok kontrol dan intervensi. Kelompok kontrol mengalami peningkatan dikarenakan pengetahuan responden (ibu) dalam membersihkan daerah perianal merupakan perilaku yang sering dilakukan oleh ibu dalam kehidupan sehari-hari terutama pada anak dengan diare. Perilaku yang dilakukan secara berulang-ulang dan terus menerus maka akan 
meningkatkan pengetahuan ibu walaupun secara langsung tidak mendapatkan edukasi perawatan perianal.

Selain itu, karakteristik responden pada kelompok kontrol dapat mempengaruhi hasil pengetahuan yang meningkat pada setelah perlakuan. Rentang umur pada kelompok kontrol 17-41 tahun, dimana usia seseorang juga mempengaruhi cara seseorang dalam menerima hal yang baru (Mubarak, dkk, 2007). Responden pada kelompok kontrol mayoritas memiliki latar belakang pendidikan menengah (SMP/SMA). Pendidikan mempengaruhi daya pemahaman seseorang terhadap informasi yang baru dan mempunyai sikap yang lebih positif menerima informasi, serta perubahan perilaku kearah yang lebih baik (Mubarak, dkk., 2007; Ahmed et al., 2012; Mollema at al., 2012). Hal ini mengindikasikan bahwa kelompok kontrol memiliki kecenderungan untuk terbuka dan lebih mudah dalam menerima informasi/masukan dari lingkungan sekitarnya serta menerapkannya dalam kehidupan sehari-hari.

Redman (1993) dalam Potter \& Perry (2006) menjelaskan bahwa pendidikan lebih tinggi akan memberikan pengetahuan lebih besar, sehingga menghasilkan kebiasaan mempertahankan kesehatan lebih baik. Selain itu, seseorang yang mengenyam pendidikan formal memiliki motivasi dan rasa keingintahuannya lebih tinggi. Kelompok intervensi sebelum dan sesudah perlakuan juga menunjukkan peningkatan pengetahuan. Hal ini dapat dilihat dari nilai rata-rata pengetahuan ibu sebelum perlakuan sebesar 50,25 dan nilai rata-rata setelah perlakuan sebesar 62,79. Peningkatan pengetahuan ini dapat dipengaruhi oleh beberapa faktor yaitu taraf pendidikan formal responden (ibu), pengalam ibu sebelumnya dalam merawat anak, kepatuhan ibu dalam melaksanakan perawatan perianal seperti yang disampaikan dalam edukasi juga menjadi faktor lain yang membuat pengetahuan ibu meningkat.

Media pembelajaran memberikan pengaruh dan motivasi untuk peserta didik. Media yang menarik akan memberikan keyakinan pada peserta didik sehingga perubahan kognitif, afektif dan psikomotor dapat tercapai maksimal. Media pembelajaran visual berupa booklet, leaflet, poster dan audiovisual terbukti mampu meningkatkan pengetahuan ibu yang diberikan pendidikan kesehatan.

Penelitian tentang peningkatan pengetahuan dan sikap ibu dalam penatalaksanaan diare menunjukkan terdapat perbedaan yang bermakna (pengetahuan $\mathrm{p}=0,01$, sikap $\mathrm{p}=0,036$ ) antara kelompok kontrol dan kelompok intervensi. Penelitian ini bertujuan untuk mengidentifikasi efektifitas audiovisual sebagai media penyuluhan terhadap perubahan pengetahuan dan sikap ibu (Kapti, 2010).

Hasil penelitian tentang risiko kerusakan integritas kulit didapatkan variabel risiko kerusakan integritas kulit sebelum dan sesudah perlakuan pada kelompok kontrol dan intervensi memiliki perbedaan yang signifikan. Kelompok kontrol mengalami penurunan disebabkan karena responden (anak) mendapatkan perawatan standar pada area perianal dengan melibatkan orang tua (ibu) dalam perawatan tersebut. Sehingga ibu dapat memperhatikan perawatan yang diberikan oleh perawat dalam membersihkan area perianal, walaupun tidak secara langsung mendapatkan edukasi tentang perawatan perianal.

Menurut Beeckman, 2009 dalam Bardlsey, (2013) perawatan kulit untuk menurunkan kejadian kerusakan integritas kulit dapat dilakukan dengan membersihkan daerah kulit, yang dilakukan dengan hati-hati dan lembut. Perawatan kulit menggunakan air putih serta usapan di area perianal dengan cara ditepuk tepuk dengan lembut mampu mengurangi gesekan dengan kulit yang dapat mencederai kulit (Livre,2002 dalam Beldon, 2008). Hasil perawatan kulit yang dilakukan sesuai standar praktik dalam penelitian ini dapat menurunkan risiko kerusakan integritas kulit. 
Vol 10 No 1 Januari 2021 | Page 64-68

\section{SIMPULAN}

Berdasarkan hasil penelitian didapatkan ada perbedaan pengetahuan dan risiko kerusakan integritas sebelum dan sesudah perlakuan pada kelompok kontrol dan intervensi.

\section{SARAN}

Tindakan edukasi keperawatan perawatan perianal dapat diusulkan untuk dijadikan sebagai standar operasional prosedur pelayanan keperawatan dalam mengatasi masalah risiko kerusakan integritas kulit pada balita yang mengalami diare.

\section{DAFTAR PUSTAKA}

Barsley, A. (2013). Prevention and managemen of incontinence-associate dermatitis. Nursing Standard. 27, 44, 41-46. Date of submission: February 19 2013; date of acceptance: April 22 2013.

Bianchi, J. (2012). Causes and strategies for moisture lesions. Journal of Nursing Times, 108 (5). 2022. Januari 31.

Hockenberry M., \& Wilson D. (2009). Wong's essential of pediatric nursing. (Ed $8^{\text {th }}$ ). USA: Mosby Elsevier

Kapti, R.E. (2010). Efektifitas audiovisual sebagai media penyuluhan kesehatan terhadap peningkatan pengetahuan dan sikap ibu dalam tatalaksana balita dengan diare di dua rumah sakit kota Malang. Tesis UI. Tidak diublikasikan

Marcdante, K.J., Kliegman, R.M., Jenson, H.B., \& Behrman, R.E. (2014). Nelson: Ilmu kesehatan anak esensial $\left(6^{\text {th }}\right.$ ed). Singapore: Mubarak, Wahit, I, dkk. (2007). Promosi kesehatan sebuah pengantar proses belajar mengajar dalam pendidikan. Yogyakarta: Graha Ilmu.

Peristein, D. (2013). Diaper rash. Available at: http://www.emedicinehealth.com/diaper-rash/page2em.htm

Potter, P.A., \& Perry, A.G. (2009). Fundamental Keperawatan. (Edisi 7). Jakarta: Salemba Medika

Puji Astuti, Y., Saputri, N., (2019). Hubungan Faktor Lingkungan dengan Kejadian Diare pada Balita di Puskesmas Bernung. Jurnal Ilmu Keperawatan dan Kebidanan. Vol 10, No 1. DOI: http://dx.doi.org/10.26751/jikk.v10i1.619

Saputri, N. Suwarsa, O. Susiarno, H. (2016). Analysis of causes of maternal mortality in Sukabumi West Java. Jurnal Aisyah: Jurnal Ilmu Kesehatan. Vol 5, No 1 (2020). DOI : https://doi.org/10.30604/jika.v5i1.209

World Health Organization. (2012). Health education: theoretical concepts, effective strategies and core competencies. http://applications.emro.who.int/dsaf/EMRPUB 2012 EN 1362.pdf 